\title{
Colony-forming units optimization and human papillomavirus detection in umbilical cord blood
}

Jisela Dimas-González, ${ }^{1}$ Jorge E. Trejo-Gómora, ${ }^{2}$ Carlos Bonilla-Cisneros ${ }^{1}$ and Alfredo Lagunas-Martínez ${ }^{*}$ ${ }^{1}$ Department of Research, National Center of Blood Transfusion, Secretaría de Salud, Mexico City; ${ }^{2}$ General Director's Office, National Center of Blood Transfusion, Secretaría de Salud, Mexico City; ${ }^{3}$ Center of Infectious Diseases Research, Secretaría de Salud, Cuernavaca, Morelos, Mexico

\begin{abstract}
Introduction: Analysis of several parameters is required for adequate quality control in umbilical cord blood units (UCBU) when used for therapeutic purposes. Objective: To optimize colony-forming units (CFU) from clonogenic cultures and to detect the human papillomavirus (HPV) genome in UCBU. Methods: One hundred and forty-one umbilical cord blood (UCB), segment or CFU samples from UCBU clonogenic cultures were included. DNA extraction, quantification and endogenous GAPDH gene PCR amplification were carried out. Subsequently, HPV L1 gene was detected using the MY09/MY11 and GP5/GP6+ oligonucleotides. PCR products were analyzed with electrophoresis in agarose gel. CFU-extracted purified DNA was analyzed by electrophoresis in agarose gel, as well as some DNAs, using the sequence-specific priming technique. Results: CFU-extracted DNA concentration was higher in comparison with that of UCB $(p=0.0041)$ and that of the segment $(p<0.0001)$, as well as that of UCB in comparison with that of the segment $(p<0.0001)$. All samples were positive for GAPDH amplification and negative for MY09/MY/11 and GP5/GP6+. Conclusions: Cryopreserved UCBUs were HPV-negative. Obtaining CFU DNA from clonogenic cultures with high concentrations and purity is feasible.
\end{abstract}

KEY WORDS: Human papillomavirus. Clonogenic cultures. Colony-forming units. Umbilical cord blood units. DNA.

\section{Optimización de unidades formadoras de colonias y detección del virus de papiloma humano en sangre de cordón umbilical}

\section{Resumen}

Introducción: Se requiere analizar diversos parámetros para el control de calidad adecuado de las unidades de sangre de cordón umbilical (USCU) cuando se utilizan con fines terapéuticos. Objetivo: Optimizar las unidades formadoras de colonias (UFC) de cultivos clonogénicos y detectar el genoma del virus del papiloma humano (VPH) en USCU. Métodos: Se incluyeron 141 muestras de sangre de cordón umbilical (SCU), de segmento y de UFC de cultivos clonogénicos de USCU. Se realizó extracción de $A D N$, cuantificación y amplificación por PCR del gen endógeno GAPDH. Se detectó el gen L1 del VPH con los oligonucleótidos MY09/MY11 y GP5/GP6+; los productos de PCR se migraron en electroforesis de agarosa. El ADN purificado de las UFC se analizó mediante electroforesis de agarosa y algunos $A D N$, con la técnica sequence specific priming. Resultados: La concentración de ADN extraído de UFC fue superior comparada con la de SCU ( $p=0.0041)$ y la de segmento $(p<0.0001)$; así como la de SCU comparada con la de segmento ( $p<0.0001)$. Todas las muestras fueron positivas para la amplificación de GAPDH y negativas para MY09/MY11 y GP5/GP6+. Conclusiones: Las USCU criopreservadas fueron VPH netativas; además, es factible obtener ADN en altas concentraciones y con alta pureza a partir de UFC de los cultivos clonogénicos.

PALABRAS CLAVE: Virus del papiloma humano. Cultivos clonogénicos. Unidades formadoras de colonias. Unidades de sangre de cordón umbilical. ADN.

Correspondence:

*Alfredo Lagunas-Martínez

E-mail: alagunas@insp.mx
Gac Med Mex. 2021;157:29-34

Contents available at PubMed

www.gacetamedicademexico.com

0016-3813/@ 2020 Academia Nacional de Medicina de México, A.C.. Published by Permanyer. This is an open access article under the CC BY-NC-ND license (http://creativecommons.org/licenses/by-nc-nd/4.0/). 


\section{Introduction}

Umbilical cord blood (UCB) is a source of hematopoietic stem cells that are used as treatment for oncological and non-oncological diseases; these cells are characterized for being pluripotent and self-renewing., ${ }^{1,2}$

The International NetCord Foundation and the Foundation for the Accreditation of Cellular Therapy (FACT) establish standardized procedures for cell therapy and UCB banks. Umbilical cord blood units (UCBU) must meet the following criteria in the respective evaluation phases:

- Prior to cryopreservation: $\geq 5.0 \times 10^{8}$ total nuclear cells, $\geq 85 \%$ cell viability, $\geq 1.25 \times 10^{6}$ CD34+ cells, $\geq 85 \%$ viable CD34+ cells, human leukocyte antigen (HLA) typing, blood group and Rh factor identification, negative microbiological cultures for aerobic and anaerobic bacteria and fungi.

- Post-cryopreservation and prior to release for transplantation (segments): $\geq 70 \%$ viable CD34+ cells, $\geq 40 \%$ viable CD $45+$ cells, CFUs growth as pre-transplant control of progenitor cells pluripotency, HLA verification. ${ }^{3}$

In addition, screening for HIV1, HIV2, HBV, HCV, cytomegalovirus, Treponema pallidum (syphilis) and Trypanosoma cruzi (Chagas disease) is carried out as quality control. It is possible to screen for other transmissible infectious agents according to the donor history, donated cells characteristics or geographic region the donor resides in. ${ }^{3}$

Human papillomavirus (HPV) is an infectious agent that can be vertically transmitted (mother-child); the term "transplacental transmission" is often used when the mother and the newborn have the same HPV genotype. So far, the mechanism of HPV transmission between mother and newborn is unknown; ${ }^{4-7}$ however, HPV DNA has been identified in UCB, the placenta, amniotic fluid and oral mucosa at birth..$^{5,8}$ Specifically, the frequency of HPV in UCB ranges from 2.2 to $6.1 \%$, and in the placenta, from 4.0 to $4.2 \%$; HPV16, HPV18, HPV39, HPV52 and HPV83 high-risk genotypes are the most common, and low-risk genotypes HPV6 and HPV11 are common in populations of Finland and Brazil. ${ }^{5,6,9}$ In addition, in newborns who are positive for the presence of the HPV genome, specifically in UCB or the placenta, there is an increased risk for persistent HPV infection in oral mucosa. .,10,11 $^{6}$

According to the above-mentioned evidence, HPV has been detected in UCB or in the placenta; therefore, the purpose of the present study was to optimize the colony-forming units (CFUs) biological sample from clonogenic cultures to extract DNA and generate a DNA biobank that allows solving HLA ambiguities or implementing other biomarkers analysis, as well as detecting the HPV genome in UCBUs from the National Center of Blood Transfusion biobank.

\section{Methods}

One hundred and forty-one biological samples from the National Center of Blood Transfusion biobank were included: 90 samples were from UCB, which are used for HLA typing prior to UCBU cryopreservation; 41 were cryopreserved UCBU segments to verify HLA and 10 were CFUs samples from clonogenic cultures, as pluripotency control. Each UCBU contains a $25-\mathrm{mL}$ bag and three segments of 50 to $200 \mu \mathrm{L}$ each, which are used for pre-transplantation control (cell quantification, HLA verification, and clonogenic cultures). The inclusion criteria were having maternal informed consent, negative family history of hereditary and communicable diseases, $\geq 34$ weeks of gestation and absence of congenital diseases. Quality control criteria were the following: UCB volume $\geq 74 \mathrm{~mL}$, total white blood cell count $>8 \times 10^{8}, \mathrm{CD} 34+$ cell count $\geq 2.0 \times 10^{6}$, negative microbiological cultures and HIV, HBV, HCV, Treponema pallidum, Trypanosoma cruzi, cytomegalovirus or toxoplasma non-reactive serology.

Clonogenic cultures are routinely carried out at the National Center of Blood Transfusion when UCBUs are reserved for transplantation; the protocol has been previously reported. ${ }^{12}$ CFUs were isolated from 10 UCBU clonogenic cultures, according to the protocol described by StemCell Technologies Inc. ${ }^{13}$

DNA extraction from UCB samples, UCBU segments and CFUs was performed with the QIAamp DNA Blood Mini Kit ${ }^{\circledR}$ (Qiagen, California, USA), according to the supplier's specifications. DNAs were quantified and stored at $-70^{\circ} \mathrm{C}$ until their use. CFU-extracted DNA integrity was evaluated on $1 \%$ agarose gel. DNA from three CFUs samples was used for HLA typing with the Micro SSPTM kit for Allele Specific HLA Class I (HLA-A, HLA-B) and Class II (HLA-DRB1, HLA-DQB1) (One (Lambda, California, USA), according to the supplier's specifications.

HPV genome detection was carried out with $500 \mathrm{ng}$ of genomic DNA from UCB samples, UCBU segments or CFUs, using the MY09/MY $11^{14}$ and GP5 $+/ \mathrm{GP} 6+^{15}$ oligonucleotides (Table 1). HeLa (HPV18) and $\mathrm{SiHa}$ (HPV16) cell lines DNA was used as positive control. 
Table 1. Oligonucleotide sequences

\begin{tabular}{|c|c|c|c|}
\hline Oligonucleotide & Sequence & $\begin{array}{l}\text { Alignment } \\
\text { temperature }\end{array}$ & $\begin{array}{l}\text { Fragment } \\
\text { size }\end{array}$ \\
\hline $\begin{array}{l}\text { GAPDH F } \\
\text { GAPDH R }\end{array}$ & $\begin{array}{l}\text { 5'-ACC ACA GTC } \\
\text { CAT GCC ATC } \\
\text { AC-3' } \\
\text { 5'-TCC ACC ACC } \\
\text { CTG TTG CTG } \\
\text { TA-3' }\end{array}$ & $57^{\circ} \mathrm{C}$ & $450 \mathrm{bp}$ \\
\hline $\begin{array}{l}\text { MY09 } \\
\text { MY11 }\end{array}$ & $\begin{array}{l}\text { 5'- CGT CCM ARR } \\
\text { GCA WAC TGA } \\
\text { TC -3' } \\
\text { 5'- GCM CAG } \\
\text { GGW CAT AAY } \\
\text { AAT GG -3' }\end{array}$ & $57^{\circ} \mathrm{C}$ & $450 \mathrm{bp}$ \\
\hline $\begin{array}{l}\text { GP5+ } \\
\text { GP6+ }\end{array}$ & $\begin{array}{l}\text { 5'-TTT GTT ACT } \\
\text { GTG GTA GAT } \\
\text { ACT AC-3' } \\
\text { 5'-GAA AAA TAA } \\
\text { ACT GTA AAT CAT } \\
\text { ATT C-3' }\end{array}$ & $40^{\circ} \mathrm{C}$ & $150 \mathrm{bp}$ \\
\hline
\end{tabular}

One fragment of the GAPDH gene was amplified with $100 \mathrm{ng}$ of DNA from all samples, as extracted DNA quality control (Table 1). In addition, a reaction without DNA was included as negative control at each polymerase chain reaction (PCR). The PCR products were analyzed on $2 \%$ agarose gel.

Statistical analysis was carried out with the GraphPad Prix program, version 7 (GraphPad Software, California, USA). DNA concentration and 260/280 absorbance of the different biological samples were compared with non-parametric Mann-Whitney's U-test; the results are presented as means with standard deviation. $p$-values $<0.05$ were statistically significant.

\section{Results}

The characteristics of the UCBUs included in the study are described in table 2 . The range of total white blood cells percentage was 60 to $>90 \%$, while total white blood cells initial range was 8.0 to $>18.0 \times 10^{8}$, and CD34+ cells final range was 2.0 to $>5.0 \times 10^{6}$; these parameters meet the criteria established by NetCord-FACT for UCBUs to be used for therapeutic purposes (Table 2).

To optimize cryopreserved UCBUs in the biobank, DNA extraction from CFUs obtained from clonogenic cultures was carried out (Fig. 1A). Figure 1B is a representative image of an agarose gel with CFUs purified DNA samples; at the top of each lane, a band can be seen to confirm DNA integrity with no degradation.
Table 2. Umbilical cord blood units characteristics

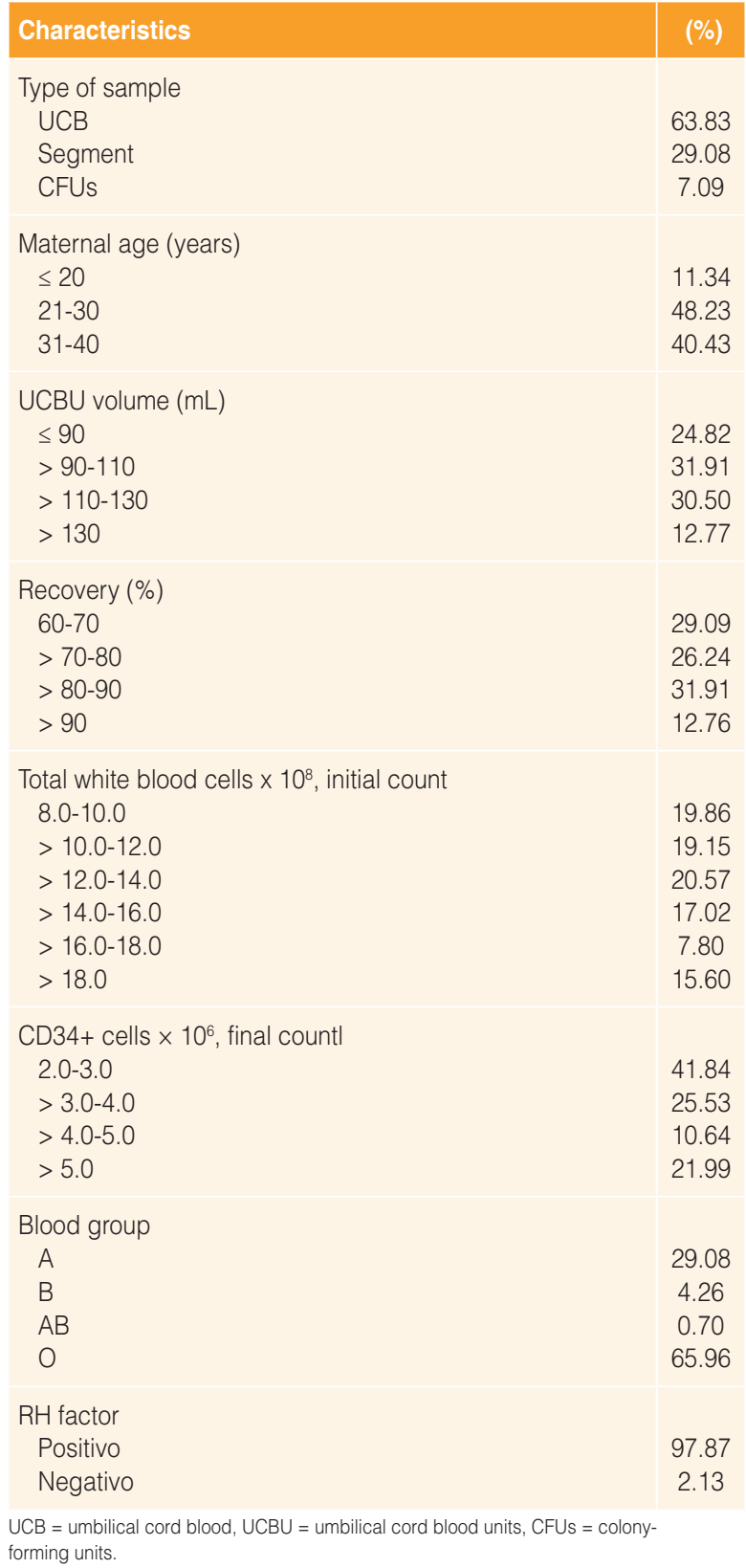

Figure $1 \mathrm{C}$ shows HLA typing, where DNA purified from a CFUs sample was used for annealing; the upper band corresponds to endogenous $\beta$-globin gene amplification, which confirms the integrity of the reaction; lower bands correspond to amplification of specific HLA alleles in the sample. The results confirm HLA typing of the three selected CFU DNA samples, since UCBUs had already been typed with UCB prior to cryopreservation or from the thawed segment, with the same HLA results being obtained. The results show the potential applications of CFUs to obtain DNA, RNA or proteins for further testing. 

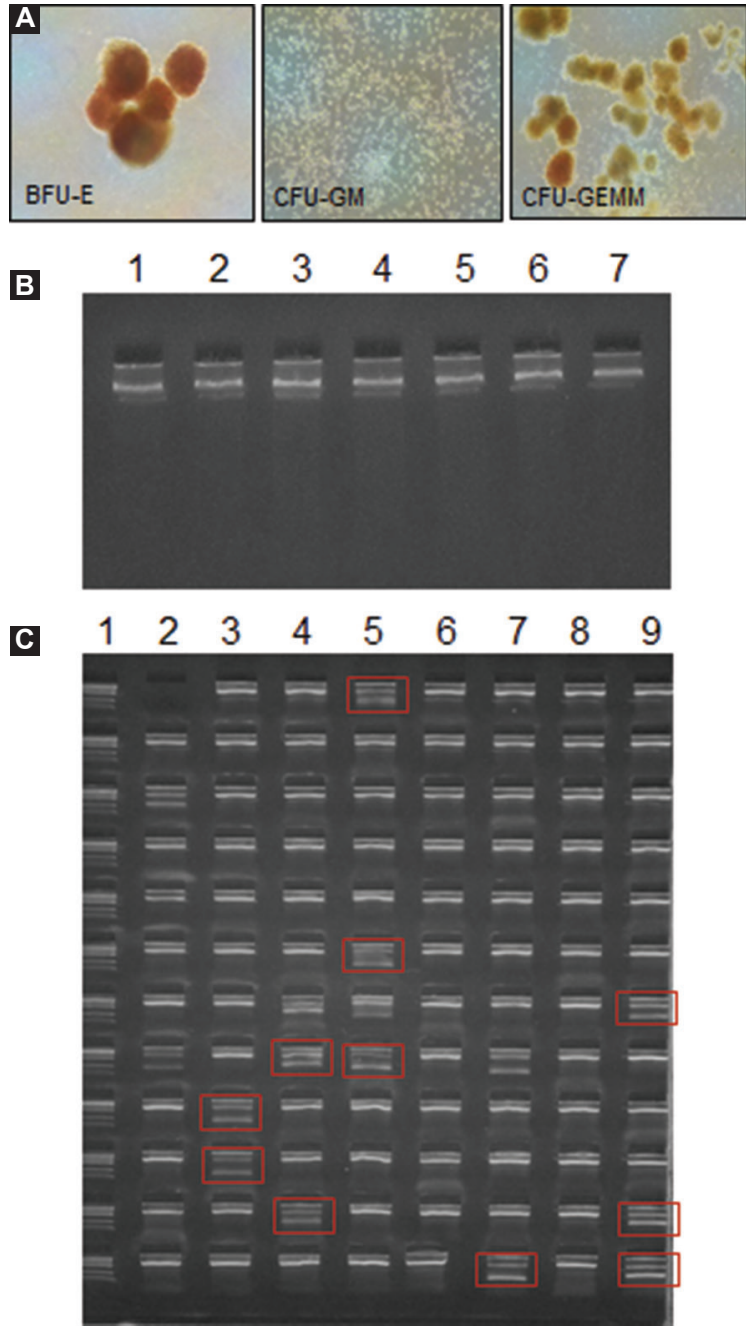

Figure 1. Clonogenic cultures' CFUs representative images. A) Clonogenic cultures' CFUs. BFU-E, burst-forming-unit-erythroid; CFU-GM, colony-formed-unit-granulocyte-macrophage; CFU GEMM, granulocyte-erythrocyte-monocyte-megakaryocyte. B) Electrophoresis of DNA extracted from CFUs in $1 \%$ agarose gel. C) HLA typing of a CFUs DNA sample using the sequence-specific priming technique. Lane 1, molecular weight marker; lane 2, upper left panel, control reaction without DNA; lanes 2 to 9, reactions with CFUs DNA (upper band, internal control; lower bands, HLA alleles specific for each sample). The detected alleles are shown in a box and are interpreted according to their size. CFUs = colony-forming units.

For the detection of HPV by PCR, DNA extraction was carried out. Figure 2A shows the distribution of all samples included in the study with regard to total DNA concentration within a range from 1.51 to 96.2 $\mu \mathrm{g}$ and the $260 / 280$ absorbance ratio within a range from 1.40 to 2.05. Subsequently, total DNA concentration in the different types of biological samples was compared; the mean in UCB was $25.81 \mu \mathrm{g}$, which was statistically significant in comparison with the mean value in the segment, which was $11.19 \mu \mathrm{g}(\mathrm{p}<0.0001)$.

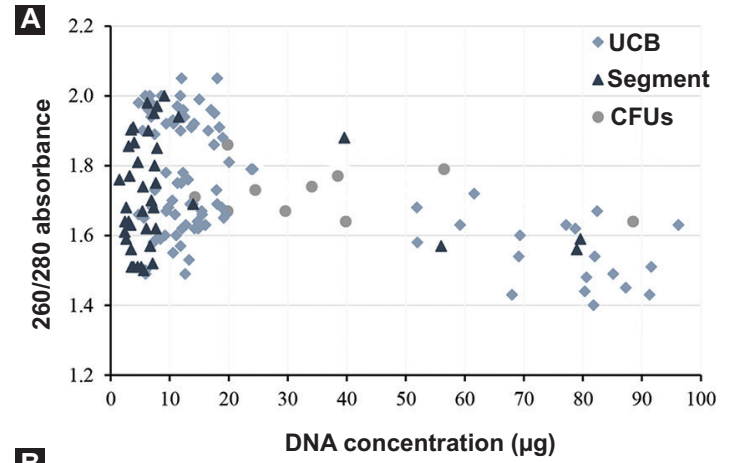

B
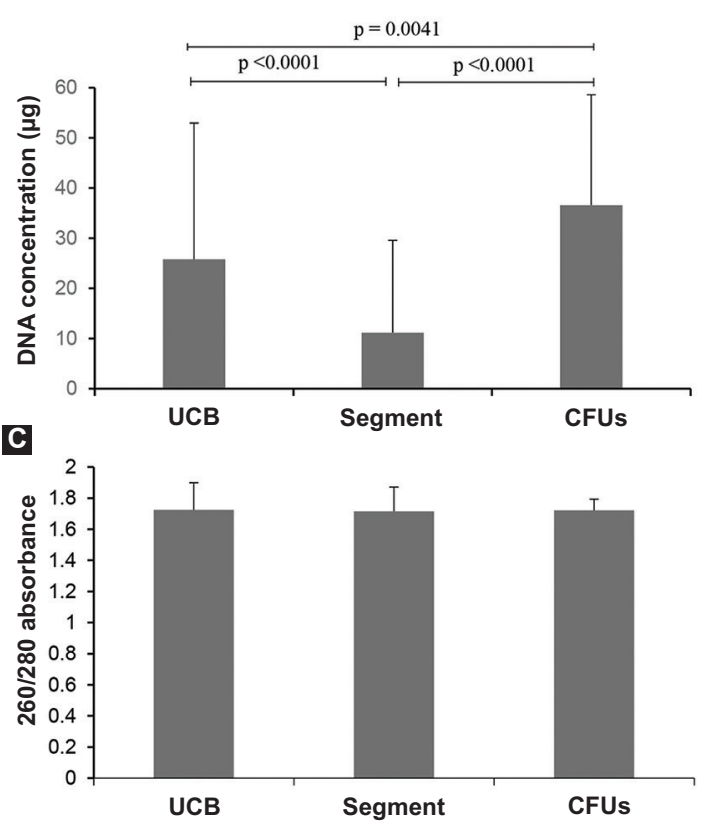

Figure 2. DNA purified from UCB, segment and CFUs. A) Purified DNA samples distribution. B) Total DNA concentration. C) 260/280 absorbance ratio. The results were plotted as means and standard deviation. UCB = umbilical cord blood, CFUs = colony-forming units.

Mean concentration in CFUs was $36.56 \mu \mathrm{g}$, which was statistically significant in comparison with the mean in UCB $(p=0.0041)$ and the mean in the segment $(p<$ 0.0001 ) (Fig. 2B). However, when the 260/280 absorbance of the different types of samples was compared, no statistically significant differences were identified (Fig. 2C).

Once the DNA samples were quantified (in UCB, segment and CFUs), HPV genome detection was carried out in all samples. Detection was carried out by PCR amplification of a $450 \mathrm{bp}$ fragment of HPV L1 gene with the MY09/MY11 oligonucleotides (Fig. 3A) and a $150 \mathrm{bp}$ fragment of the same gene with the GP5+/GP6+ oligonucleotides (Fig. 3B); we did not detect any positive HPV sample with any of the employed oligonucleotides. In addition, to verify DNA 


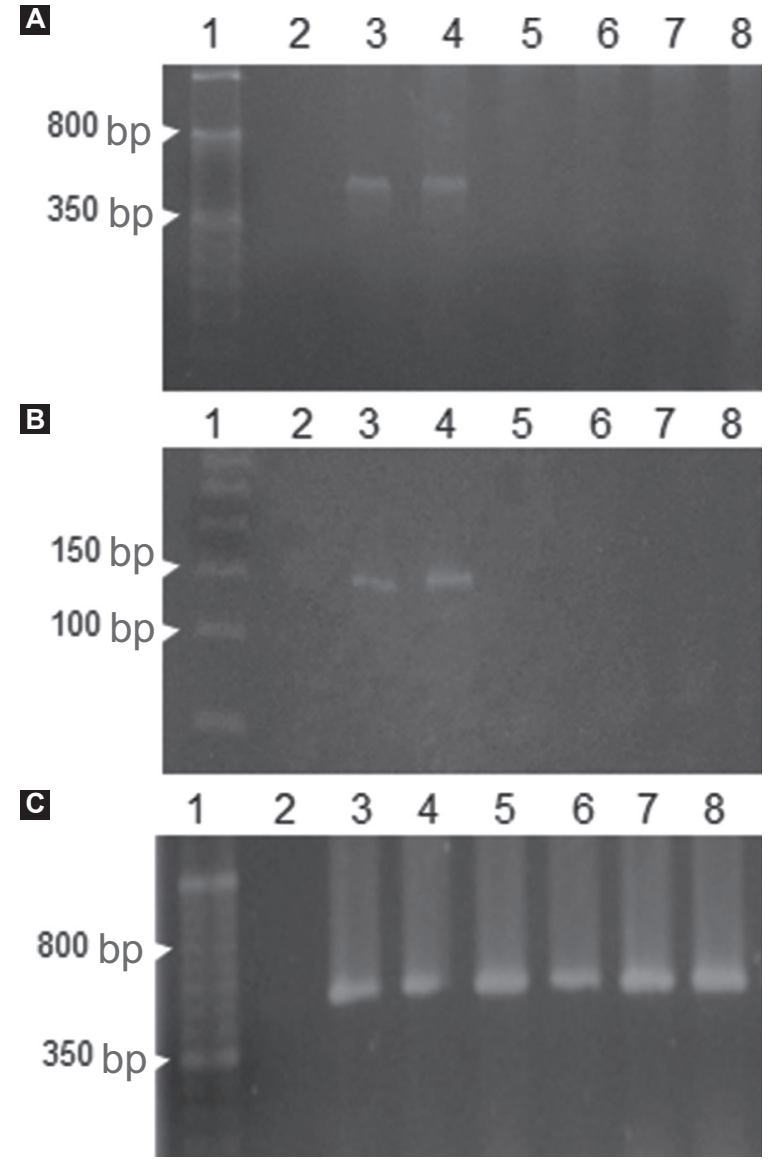

Figure 3. Representative images of HPV detection in UCBUs. A) L1 gene PCR with the MY09/MY11 oligonucleotides, which amplify a 450 bp fragment. B) L1 gene PCR with the GP5+/GP6+ oligonucleotides, which amplify a 150-bp fragment. C) GAPDH gene PCR, which amplifies a 450-bp fragment. Lane 1, molecular weight marker; lane 2, negative control without DNA; lane 3, HeLa cell line DNA; lane 4, SiHa cell line DNA; lane 5-8, UCBU DNA samples. HPV = human papillomavirus, UCBU = umbilical cord blood unit, $P C R=$ polymerase chain reaction.

integrity, a 450-bp fragment of the GAPDH gene was amplified as endogenous control, whereby amplification of all DNA samples included in the study was observed (Fig. 3C).

\section{Discussion}

National Center of Blood Transfusion biobank cryopreserved UCBUs were HPV-negative, an additional quality control parameter for UCBUs to be transplanted. Optimization of CFUs obtained from clonogenic cultures will allow generating a DNA biobank with adequate purity and concentration for solving HLA ambiguities or for analysis of other biomarkers to be implemented.

In the present study, we included purified DNA samples from clonogenic cultures' CFUs. Although there is a StemCell Technologies Inc. protocol for extracting nucleic acids, there is no evidence regarding their use in molecular biology techniques for in vitro diagnosis. We observed a higher mean DNA concentration in this type of sample with regard to the concentration of DNA extracted from UCB prior to its cryopreservation or from the thawed segment. It should be noted that DNA concentration depends on the number of CFUs and their size in clonogenic cultures; however, when a correlation was made between DNA concentration and CFUs total number, a positive correlation was not found (data not shown), given that CFUs size also influences.

In samples of UCB thawed segments, a lower mean DNA concentration was obtained, an expected result given that each UCB segment contains a 50 to $200 \mu \mathrm{L}$ volume; in addition, the segments were cryopreserved for months or years, which, as it is known for cryopreservation and thawing processes, affects cell viability and hematopoietic stem cells function..$^{16-18}$ Sample storage time has been reported to likely affect DNA concentration and purity due to nucleic acids natural degradation process. ${ }^{19-21}$

Another DNA important variable is purity. We obtained a 260/280 ratio within a range from 1.64 to 2.05 , with no statistically significant differences between the different groups that were analyzed. Among the specifications for HLA typing using SSP and sequence-specific oligonucleotide techniques, an absorbance ratio of 1.65 to 1.80 is required, which is met with the purity values that were obtained. In addition, the optimal ratio of DNA quantified at the 260/280 wavelengths should be higher than 1.80; a ratio $>2.1$ indicates the presence of RNA in the sample and a ratio $<1.60$ indicates the presence of proteins or contaminants. ${ }^{22}$

Regarding HPV genome detection, we did not find any positive UCBU, which represents an additional quality control in the detection of an infectious agent for these units to be transplanted. One disadvantage of the study was the sample size $(n=141)$, since HPV has been observed in UCB with a frequency of 2.2 to $6.1 \%: 5,6,9$ therefore, it would be advisable to increase the sample size. HPV genotypes that are frequently identified in UCB include high-risk HPVs that are associated with impaired immune response, premalignant lesions and cancer. ${ }^{5,6,9,10,11}$ Therefore it would be pertinent to analyze the presence of HPV in a larger UCBU sample.

In conclusion, the analyzed UCBUs were HPV-negative; in addition, DNA extraction from CFUs obtained 
from clonogenic cultures will allow the generation of a DNA biobank in order for other biomarkers to be implemented in the future, and thus solve HLA ambiguities or implement research protocols.

\section{Acknowledgements}

To the German Academic Exchange Service (DAAD - Deutscher Akademischer Austauschdienst), for providing equipment and accessories to carry out this research protocol.

\section{Conflict of interests}

None.

\section{Funding}

This study protocol was developed with resources from the National Center of Blood Transfusion and the National Institute of Public Health.

\section{Ethical disclosures}

Protection of human and animal subjects. The authors declare that no experiments were performed on humans or animals for this research.

Confidentiality of data. The authors declare that they followed the protocols of their work center on the publication of patient data.

Right to privacy and informed consent. The authors obtained informed consent from the patients or subjects referred to in the article. This document is in the possession of the corresponding author.

\section{References}

1. Hordyjewska A, Popiolek L, Horecka A. Characteristics of hematopoietic stem cells of umbilical cord blood. Cytotechnology. 2015;67:387-396.

2. Narayanan DL, Phadke SR. Concepts, utility and limitations of cord blood banking: What clinicians need to know. Indian J Pediatr. 2019;86:44-48.

3. NetCord-Fact. International standards for cord blood collection, banking, and release for administration accreditation manual. Foundation for the Accreditation of Cellular Therapy; 2015.
4. Tseng CJ, Liang CC, Soong YK, Pao CC. Perinatal transmission of human papillomavirus in infants: relationship between infection rate and mode of delivery. Obstet Gynecol. 1998;91:92-96.

5. Rombaldi RL, Serafini EP, Mandelli J, Zimmermann E, Losquiavo KP. Transplacental transmission of human papillomavirus. Virol J. 2008;5:106.

6. Sarkola ME, Grénman SE, Rintala MAM, Syrjänen KJ, Syrjänen SM. Human papillomavirus in the placenta and umbilical cord blood. Acta Obstet Gynecol Scand. 2008;87:1181-1188.

7. Rombaldi RL, Serafini EP, Mandelli J, Zimmermann E, Losquiavo KP. Perinatal transmission of human papilomavirus DNA. Virol J. 2009;6:83.

8. Tseng CJ, Lin CY, Wang RL, Chen LJ, Chang YL, Hsieh TT, et al. Possible transplacental transmission of human papillomaviruses. Am J Obstet Gynecol. 1992;166:35-40.

9. Teixeira LO, Amaral SC, Finger-Jardim F, da Hora VP, Goncalves CV, Soares MA, et al. Frequency of human papillomavirus in the placenta, in the colostrum and in the umbilical cord blood. Rev Bras Ginecol Obstet. 2015;37:203-207.

10. Koskimaa HM, Waterboer T, Pawlita M, Grénman S, Syrjänen K, Syrjänen $S$. Human papillomavirus genotypes present in the oral mucosa of newborns and their concordance with maternal cervical human papillomavirus genotypes. J Pediatr.. 2012;160:837-843.

11. Koskimaa HM, Paaso A, Welters MJP, Grénman S, Syrjanen K, van der Burg, et al. The presence of human papillomavirus (HPV) in placenta and/or cord blood might result in Th2 polarization. Eur J Clin Microbio Infect Dis. 2017;36:1491-1503.

12. Dimas-González J, Nieto-Linares A, Millán-Rocha M, Salazar-Bailón JL, Lorenzo-Moreno BA, Rojo-Medina J. Thawing methods do not affect cell viability of CD45+ and CD34+ cells, but long-term cryopreservation of umbilical cord blood units generally decreases cell viability. Transfus Apher Sci. 2019;58:196-200.

13. stemcell.com [Internet]. Stemcell ${ }^{\mathrm{TM}}$ Technologies; c2019.

14. Bernard HU, Chan SY, Manos MM, Ong CK, Villa LL, Delius H, et al. Identification and assessment of known and novel human papillomaviruses by polymerase chain reaction amplification, restriction fragment length polymorphisms, nucleotide sequence, and phylogenetic algorithms. J Infect Dis. 1994;70:1077-1085.

15. de Roda Husman AM, Walboomers JM, van den Brule AJ, Meijer CJ, Snijders PJ. The use general primers GP5 and GP6 elongated at their 30end with adjacent highly conserved sequences improves human papiIlomavirus detection by PCR. J Gen Virol. 1995;76:1057-1062.

16. Zhang XB, Li K, Yau KH, Tsang KS, Fok TF, Li CK, et al. Trehalose ameliorates the cryopreservation of cord blood in a preclinical system and increases the recovery of CFUs, long-term culture-initiating cells, and nonobese diabetic-SCID repopulating cells. Transfusion. 2003;43:265-272.

17. Broxmeyer HE, Lee MR, Hangoc G, Cooper S, Prasain N, Kim YJ, et al. Hematopoietic stem/progenitor cells, generation of induced pluripotent stem cells, and isolation of endothelial progenitors from 21 - to 23.5 years cryopreserved cord blood. Blood. 2011;117:4773-4777.

18. Pasha R, Elmoazzen H, Pineault N. Development and testing of a stepwise thaw and dilute protocol for cryopreserved umbilical cord blood units. Transfusion. 2017:57:1744-1754.

19. Gail MH, Sheehy T, Cosentino M, Pee D, Diaz-Mayoral NA, Garcia-Closas $M$, et al. Maximizing DNA yield for epidemiologic studies: no more buffy coats? Am J Epidemiol. 2013;178:1170-1176.

20. Hara M, Nakanishi H, Yoneyama K, Saito K, Takada A. Effects of storage conditions on forensic examinations of blood samples and bloodstains stored for 20 years. Leg Med (Tokyo). 2016;18:81-84.

21. Ferro P, Ortega-Pinazo J, Martínez B, Jiménez Á, Gómez-Zumaquero JM, Hortas ML, et al. On the use of buffy or whole blood for obtaining DNA of high quality and functionality: what is the best option? Biopreserv Biobank. 2019;17:577-582.

22. Glasel JA. Validity of nucleic acid purities monitored by $260 \mathrm{~nm} / 280 \mathrm{~nm}$ absorbance ratios. Biotechniques. 1995;18:62-63. 